SERGEI M. GOLUBKOV ${ }^{1 \star}$

MikHAIL S. GOLUBKOV ${ }^{1}$

EVGENIA V. BALUSHKINA ${ }^{1}$

LARISA F. LITVINCHUK ${ }^{1}$

\title{
Biotic interactions, energy pathways and trigger factors of ecosystem dynamics in shallow saline lakes
}

Key words: saline lakes, primary production, secondary production, zooplankton, zoobenthos, energy pathways, regime shift

\section{Summary}

Environmental variables, food-web dynamics and energy pathways were investigated in ecosystems of six shallow lakes of the Crimea with salinity ranging from 24 to $340 \%$. There were considerable inter- and intra-annual fluctuations in the abiotic characteristics of the lakes. All the lakes had a very high concentration of total phosphorus in the water (up to $5.6 \mathrm{gP}$ $\mathrm{m}^{-3}$ ) due to a great influence of the watershed on the lakes. A high level of primary production (up to $14.9 \mathrm{gC} \mathrm{m}^{-2} \mathrm{~d}^{-1}$ ) was found in the most of the lakes. The lowest primary production was found in the most saline lake with a dense population of the filtrator, Artemia urmiana. Grazing benthic energy pathways were dominant at salinities between 24 and $58 \%$. Greater levels of salinity led to a gradual reduction of benthic and increase of planktonic energy pathways. A fast shift from turbid to clear-water regime was observed in one of the lakes, caused by annual variations in weather conditions.

1 Russian Academy of Sciences, Zoological Institute, Universitetskaya Nab. 1, 199034, St. Petersburg, Russia, *e-mail: golubkov@zin.ru 


\section{Introduction}

Hypersaline lakes and lagoons are widespread in arid and semi-arid climatic zones (Williams 1998). Due to energy flow and carbon cycling, these aquatic systems play an important role in global biochemical processes and are known for high rates of organic matter and calcium carbonate burial. Nevertheless, there are only a few studies of food web structure and functioning of these ecosystems (Vareschi 1987, Alcorlo et al. 2001). One of the reasons for the shortage of such information is a great seasonal and interannual variability of environment in saline lakes (Strachlow et al. 2005). Pronounced changes in water and salinity levels may act as catastrophic disturbance events causing regime shifts in the lake ecosystems (Williams 2002, Strachlow et al. 2005). The most traditional and successful direction of research dealing with biota of salt lakes is investigations of the influence of salinity upon the species composition and abundance of planktonic and benthic communities (e.g. Timms 1981, Pinder et al. 2005). They have shown that diversity of planktonic and benthic communities decrease with increasing salinity. That may influence the ecosystem function (Golubkov et al. 2007). Primary (natural) and secondary (anthropogenic) salinization may be considered as a major threat to the lake ecosystem integrity and amount of water resources in semi-arid and arid regions of the world (Williams 2002, Strachlow et al. 2005).

The conceptual model, which has been successfully applied recently to examine impacts of salinization and eutrophication on salt lakes and wetland by Australian scientists (Davis et al. 2003, Strachlow et al. 2005, Timms 2005, Sim et al. 2006a, 2006b, Segal et al. 2006), can be considered as an alternative to the above presented influence of salinization on lake ecosystem They suggested that a moderate salinity results in the dominance of a small number of salt-tolerant species of macrophytes and with the increasing salinity the system shifts to a benthic microbial community composed mostly of cyanobacteria and halophilic bacteria. This model was successfully applied to describe alternative states in Australian wetlands. 
The present study was designed to provide more information about the changes in food web structure and energy pathways in hypersaline lakes and to designate the factors responsible for dynamics of their ecosystems. We suggested that an increase in salinity is followed by a decrease of biodiversity causing a shortening of food webs and that salinity fluctuations may cause shifts in ecosystem water regime along the salinity gradient.

\section{Materials and methods}

Energy fluxes and food web dynamics were investigated in the ecosystems of six saline lakes: Kojashskoe, Tobechikskoe, Kirkojashskoe, Shimakhanskoe, Marfovskoe and Bakalskoe in spring, late summer and winter of 2004 and 2005. The lakes are situated in the eastern and western parts of the Crimea. Their general morphometric characteristics are given in Table 1. Narrow spits separate three lagoon-derived lakes (Kojashskoe, Tobechikskoe and Bakalskoe) from the Black Sea. Three other lakes have a continental origin and are situated in land depressions several kilometers away from the sea coast. All the lakes are shallow with a maximum depth equal or smaller than $1.55 \mathrm{~m}$ (Tab. 1). They have no inflows or outlets and are surrounded by steppe grassland. The water inflows into the lakes are the result of atmospheric precipitation, filtration from subsoil waters and from the sea (in the case of lagoon-derived lakes). There are a large village and a cattle-breeding farm on the shore of Marfovskoe Lake.

Temperature, salinity, Secchi depth $(\mathrm{Sec})$ and concentration of total phosphorus in the water were determined at 2-3 sampling stations in each lake. Water samples were hydrolysed with $\mathrm{H}_{2} \mathrm{SO}_{4}$ and the molybdate "blue" method (Golterman 1969) was used to evaluate the total phosphorus concentration. Suspended particulate matter $(P M)$ content in the water was determined after a filtration through Sinpore filters $(0.85 \mu \mathrm{m})$ using gravimetric technique. Before the weighting, the filters were washed in distilled water. Each filter was neatly put upward on the Petri dish with distilled water, and salt from the filter passed to the distilled water. After that the filters 
were dried and weighed. The concentration of particulate matter was calculated from the difference between the weight of filters before and after the filtration. Particulate organic matter (POM) content was determined after a filtration through the Whatman GF/F filters $(0.7 \mu \mathrm{m})$ with a subsequent dichromate acid oxidation (Golterman 1969). Chlorophyll $a$ concentrations were estimated by filtering 100 $\mathrm{ml}$ of water samples through $0.85 \mathrm{~mm}$ Sinpor filters, followed by a $90 \%$ aceton extraction and spectrophotometric determination at two wavelengths (Stricland and Parsons 1968). Salinity of the water was determined by means of ATAGO S/MILL salinity refractometer.

Table 1. Limnological features of six hypersaline lakes in the Crimea in 2004-2005

\begin{tabular}{|c|c|c|c|}
\hline Lake Origin & Coordinates & $\begin{array}{l}\text { Area } \\
\mathrm{km}^{2}\end{array}$ & $\begin{array}{c}\text { Maximum depth } \\
\mathrm{m}\end{array}$ \\
\hline Kojashskoe Lagoon derived & $\begin{array}{c}45^{\circ} 02^{`} 50^{“} \mathrm{~N}, \\
36^{\circ} 11^{\prime} 10^{“} \mathrm{E}\end{array}$ & 7.00 & 0.50 \\
\hline Tobechikskoe Lagoon derived & $\begin{array}{l}45^{\circ} 10^{`} 35^{\prime \prime} \mathrm{N}, \\
36^{\circ} 22^{\prime} 10^{\prime \prime} \mathrm{E}\end{array}$ & 20.00 & 1.45 \\
\hline Bakalskoe Lagoon derived & $\begin{array}{l}45^{\circ} 44^{\prime} 45^{“ \mathrm{~N}}, \\
33^{\circ} 10^{\prime} 30^{\prime \prime} \mathrm{E}\end{array}$ & 8.00 & 0.70 \\
\hline Kirkojashskoe Continental & $\begin{array}{l}45^{\circ} 04^{\prime} 40^{“} \mathrm{~N}, \\
36^{\circ} 13^{`} 00^{\prime \prime} \mathrm{E}\end{array}$ & 1.25 & 1.55 \\
\hline Shimakhanskoe Continental & $\begin{array}{l}45^{\circ} 06^{\prime} 00^{“} \mathrm{~N}, \\
36^{\circ} 15^{`} 20^{\prime \prime} \mathrm{E}\end{array}$ & 2.64 & 1.25 \\
\hline Marfovskoe Continental & $\begin{array}{l}45^{\circ} 12^{`} 00^{\prime \prime} \mathrm{N}, \\
36^{\circ} 06^{\prime} 50^{\prime \prime} \mathrm{E}\end{array}$ & 2.65 & 0.35 \\
\hline
\end{tabular}

Rates of plankton primary production at the water surface $\left(A_{o p}\right)$ and the decomposition of organic matter were measured by means of oxygen method of light and dark bottles (Golterman 1975): bottles (100 $\mathrm{ml}$ volume) were filled with water from the sampling stations and placed at a depth of 5-10 cm for 2-6 hours in the littoral area of the lakes in the middle of the day (from 11.00 a.m.). The measurements were conducted in three replicates. The daily rate of gross primary production $\left(A, \mathrm{~J} \mathrm{~m}^{-2}\right)$ was calculated according to Håkanson and Boulion (2002): $A=A_{\text {opt }} \operatorname{Sec}$. To calculate $A$ for the diurnal interval, 
$A$ was multiplied by $T / t$, where $T$ is duration of daylight interval and $t$ is the exposition time of the bottles. The Winkler method was used to determine oxygen content in the control bottles at the beginning of the experiment and in the light and dark bottles at the end of the experiment. The values of primary production were recalculated to energy units using a factor $k=9.94 \mathrm{~J} \mathrm{mgO}_{2}^{-1}$ (Håkanson and Boulion 2002).

For algae biomass estimates, Cladophora spp. was collected at 6 stations in Tobechikskoe Lake during the intensive filamentous algae blooms in August 2005 by means of a plastic tube with $25 \mathrm{~cm}$ diameter. Samples were then dried and weighed. Rates of Cladophora primary production were determined by the oxygen method in $100 \mathrm{ml}$ dark and light bottles. After the measurements, filamentous algae mass was dried and weighed. The primary production of Cladophora algae $\left(A, \mathrm{~kJ} \mathrm{~m}^{-2}\right)$ was calculated as $A=B C_{w c l}$, where $C_{w c l}\left(\mathrm{~kJ}\left(\mathrm{gDWm}^{-2}\right)^{-1}\right)$ is a specific rate of their primary production and $B\left(\mathrm{gDWm}^{-2}\right)$ is their biomass.

To collect crustacean zooplankton, 601 of water were filtered through a $110 \mu \mathrm{m}$ plankton net. Rotifer samples were collected directly in $500 \mathrm{ml}$ bottles. Zoobenthos was sampled using a Petersen grab $\left(1 / 40 \mathrm{~m}^{2}\right)$ or a core sampler $\left(1 / 250 \mathrm{~m}^{2}\right)$ and sieved in the field using a $0.25 \mathrm{~mm}$ mesh. Each sampling had 3 replicates at each station. Samples of zooplankton and zoobenthos were preserved in $4 \%$ formalin before species identification and counts. Weight $W$ of zooplankton was calculated by means of equations $W(\mathrm{DW}, \mathrm{mg})=0.00103 L^{2.66}$ for Artemia spp. (Khmeleva 1968), $W(\mathrm{WW}, \mathrm{mg})=0.036 \mathrm{~L}^{2.74}$ for Arctodiaptomus salinus (Daday) (Salazkin et al. 1984), W (WW, mg) $=0.074 L^{3.05}$ for Moina mongolica Daday (Balushkina and Winberg 1979), $W(\mathrm{WW}, \mathrm{mg})=0.12 L^{3.00}$ for Rotifera (Ruttner-Kolisko 1977), where $L$ is length (mm) of animals. According to Khmeleva (1968), dry weight of Artemia averages approximately $11 \%$ of wet weight.

To calculate the metabolic losses of energy in the process of respiration $\left(D, \mathrm{~kJ} \mathrm{~m}^{-2} \mathrm{~d}^{-1}\right)$ of the zooplankton and zoobenthos the following equations describing relationships between the respiration rate $R_{20}$ 
$\left(\mathrm{mlO}_{2} \mathrm{~h}^{-1}\right)$ and wet body weight of animals $W(\mathrm{~g})$ at the temperature of $20^{\circ} \mathrm{C}$ were used:

Artemia spp.: $R_{20}=0.082 W^{0.702}$ (Suschenya 1972),

Arctodiaptomus salinus: $R_{20}=0.200 W^{0.759}$ (Suschenya 1972),

Moina mongolica: $R_{20}=0.143 W^{0.803}$ (Suschenya 1972),

Rotifera: $R_{20}=0.106 W^{0.796}$ (Galkovskaya 1980),

Polychaeta: $R_{20}=0.130 W^{0.810}$ (Kamliuk 1974),

Amphipoda: $R_{20}=0.142 W^{0.790}$ (Suschenya 1972),

Chironomidae: $R_{20}=0.088 W^{0.750}$ (Balushkina 1987),

Others: $R_{20}=0.143 W^{0.750}$ (Hemmingsen 1960).

The mean body weight of different groups of animals found in the samples was used for calculating $R_{20}$. Van't Goff's coefficient $\left(Q_{10}=\right.$ 2.25) was used to adjust $R_{20}$ to the actual water temperature (Winberg 1983): $R=R_{20} 2.25$ (T-20)/10. The respiratory losses of energy by animal communities (zooplankton or zoobenthos) was calculated as $D$ $=24 R k N$, where $N$ is the animal numbers, and $k$ is the oxycalorific coefficient equal to $3.4 \mathrm{kcal} \mathrm{mlO}_{2}^{-1}$ or $14.2 \mathrm{~J} \mathrm{mlO}_{2}^{-1}$ (Winberg and Duncan 1971).

Daily production $\left(P, \mathrm{~kJ} \mathrm{~m}^{-2} \mathrm{~d}^{-1}\right)$ of zooplankton and Polychaeta was calculated by means of production efficiency coefficient $K_{2}: P=D K_{2} /$ $\left(1-K_{2}\right)$ (Winberg and Duncan 1971). The value of $K_{2}$ was accepted as 0.4 for Rotifera and Polychaeta, 0.3 for Cladocera (Salazkin et al. 1984) and 0.6 for Artemia spp. (Khmeleva 1968).

Daily production of chironomids was calculated according to the equation of Balushkina and Petrova (1989):

$$
P=0.08 W^{1.07} \mathrm{~N} \mathrm{~K} \text {, }
$$

where $W$ is the mean body weight of chironomid larvae (WW, g), $N$ is their abundance (ind. $\mathrm{m}^{-2}$ ) and $K$ is the calorific value of biomass unit $\left(\mathrm{kJ} \mathrm{gWW}^{-1}\right)$.

Daily production of other benthic animals was calculated as $P=$ $C_{w} B K$, where $C_{w}$ is the specific daily rate of production $\left(\mathrm{kJ} \mathrm{m}^{-2} \mathrm{~d}^{-1}\right.$ $\left.\left(\mathrm{gWW} \mathrm{m}^{-2}\right)^{-1}\right), B$ is their biomass $\left(\mathrm{gWW} \mathrm{m}^{-2}\right)$ and $K$ as above is the calorific value of biomass unit $\left(\mathrm{kJ} \mathrm{gWW}^{-1}\right)$. Specific rate of production was calculated as:

Amphipoda: $C_{w}=-0.044+0.239 W^{-0.36}($ Panov 1988), 
Coleoptera: $C_{w}=0.0049 e^{0.092} T$ (Golubkov 2000), where $T$ is water temperature.

For Oligochaeta and Hirudinea $C_{w}$ was accepted as 0.03 (Finogenova and Lobasheva 1987), for Gastropoda -0.01 and for Bivalvia - 0.025. Rates of food consumption $\left(C, \mathrm{~kJ} \mathrm{~m}^{-2}\right)$ were calculated as $C=(P+R) / U$, where $U$ is efficiency coefficient of food assimilation (accepted as 0.8 for predators and 0.6 non-predators). Calorific value of a biomass unit was assumed to be $11 \mathrm{~kJ} \mathrm{gWW}^{-1}$ for Arthropoda, $4.7 \mathrm{~kJ} \mathrm{gWW}^{-1}$ for Bivalvia with shell and $7.7 \mathrm{~kJ} \mathrm{gWW}^{-1}$ for Gastropoda with shell (Golubkov 2000).

NAO (North Atlantic Oscillation) index, also number of windy days (with wind speed greater then $5 \mathrm{~m} \mathrm{sec}^{-1}$ ) and air temperature in the eastern Crimea were used to evaluate the role of the weather conditions in ecosystem regime shift in Tobechikskoe Lake. Average NAO index values for spring and summer months of 2004 and 2005 were calculated from http://www.cpc.noaa.gov/products/precip/CWlink/ pna/norm.nao.monthly.b5001.current.ascii.Tab. Data on wind speed and air temperature were received from http://www.gismeteo.ru.

\section{Results}

\subsection{Lake abiotic characteristics and primary production}

All the lakes had very high concentrations of total phosphorus $P_{\text {tot }}$ in the water (Tab. 2). The highest concentrations of $P_{\text {tot }}$ were observed in Marfovskoe Lake due to a run off from the large village and cattle-breeding farm. Only $5 \mathrm{~cm}$ Secchi depth was measured in this lake in summer 2005. The other lakes also had very high average concentrations of $P_{\text {tot }}$ in the water. On the other hand, a decrease in $P_{\text {tot }}$ was observed in Bakalskoe Lake in 2005, as compared to 2004, probably as a result of the partial rupture of its spit and the input of marine water into the lake. The concentration of suspended particulate matter $P M$ in the most saline Kojashskoe Lake reached almost $1 \mathrm{~kg} \mathrm{~m}^{-3}$ in April and August 2005, and as a result the Secchi depth 


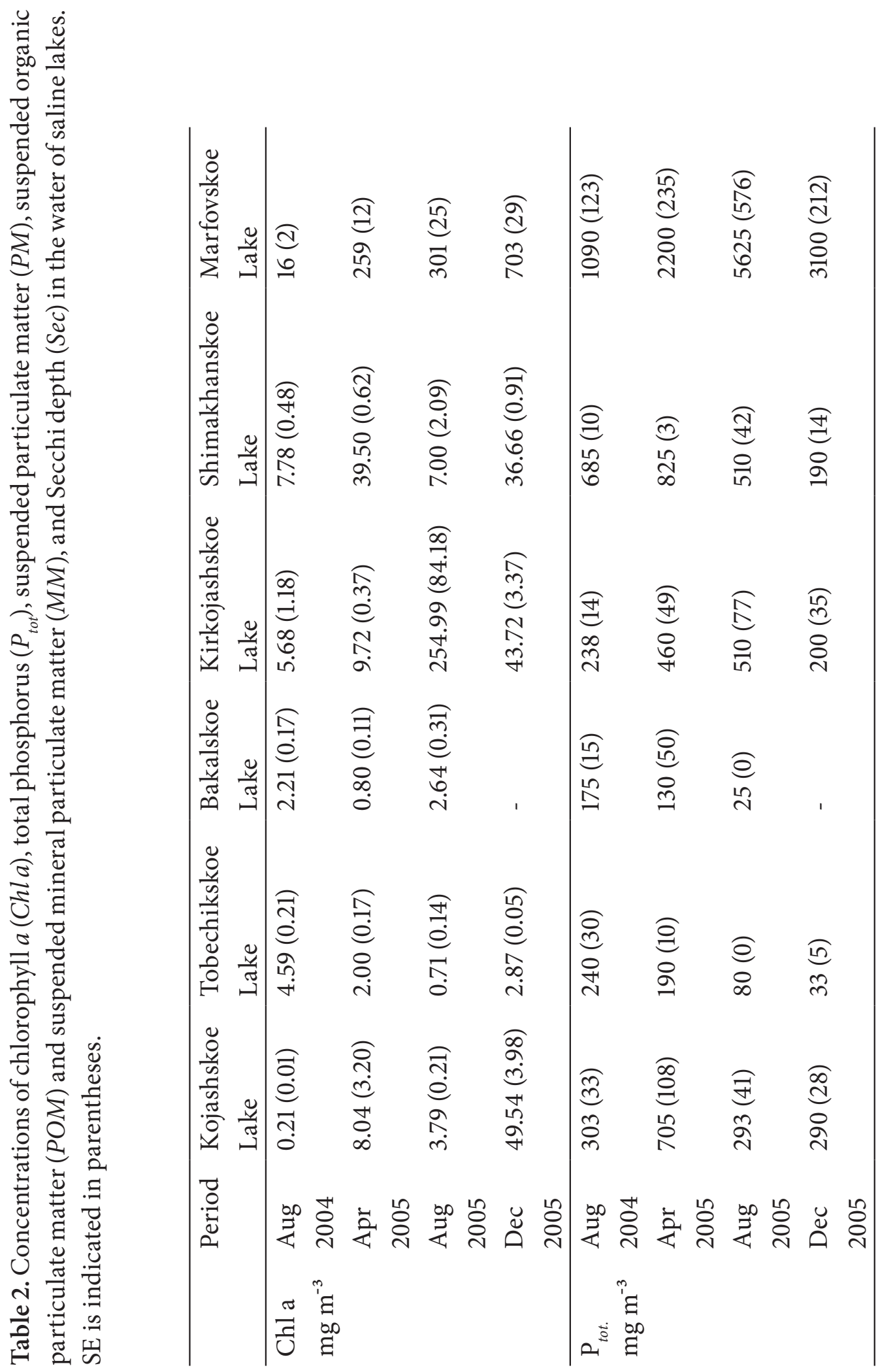




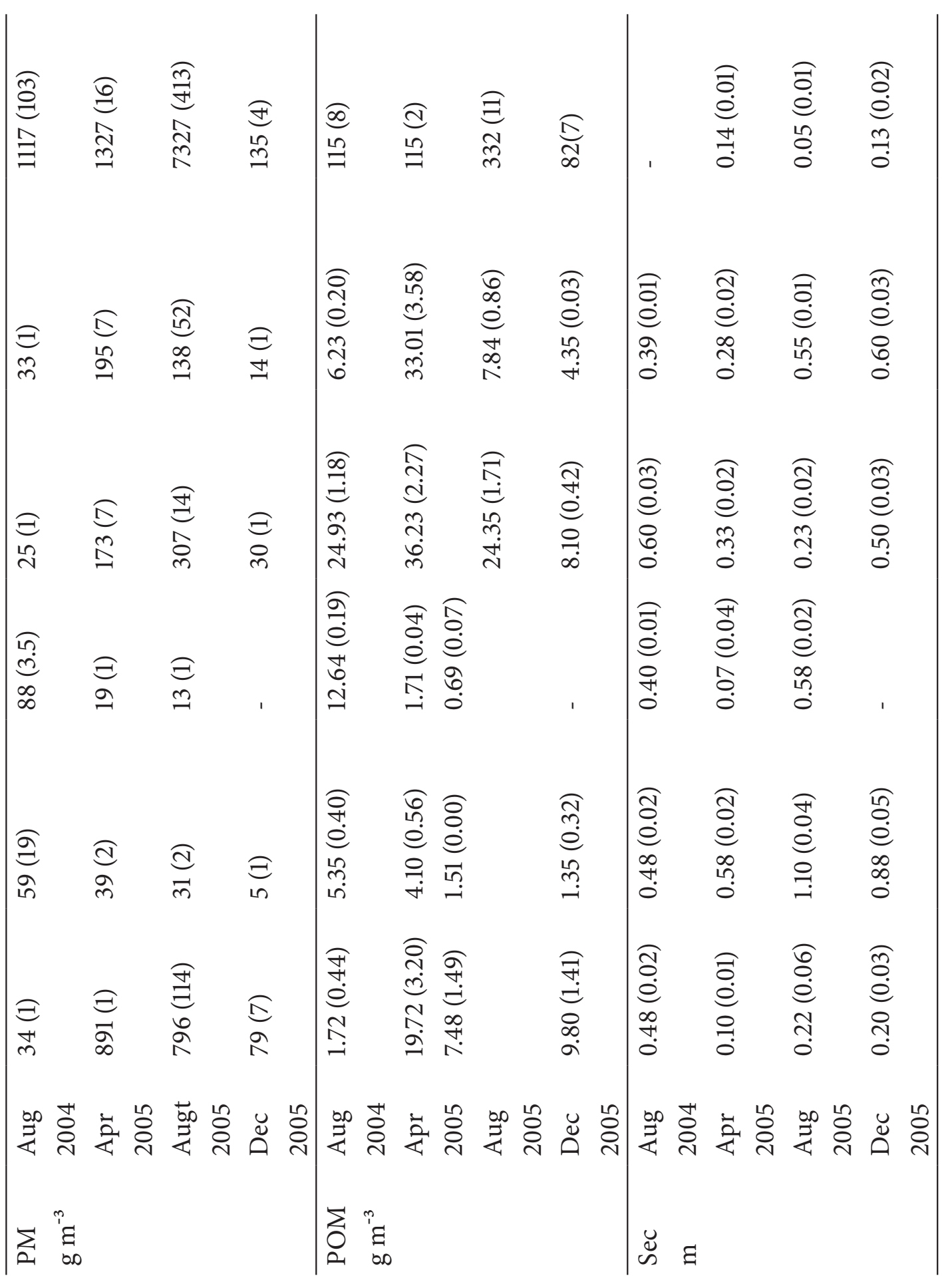




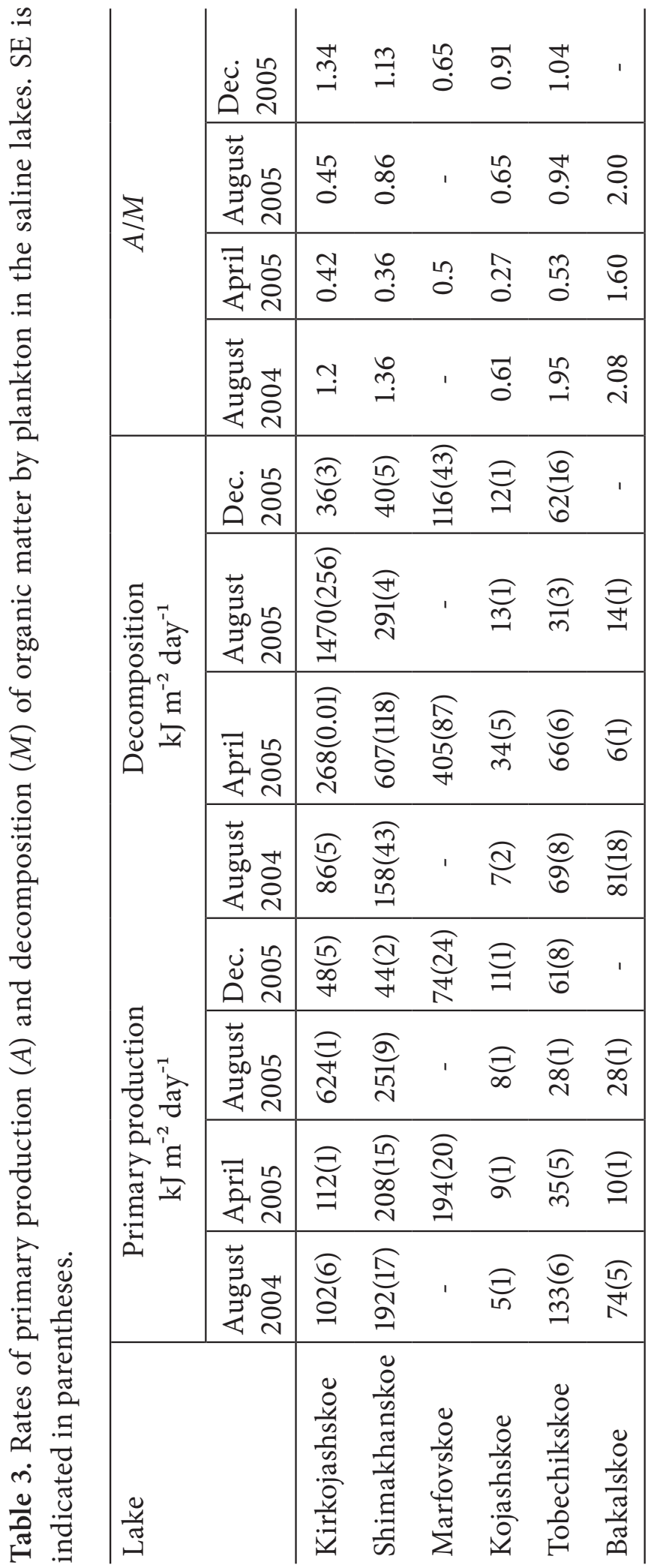


was only about $0.2 \mathrm{~m}$ at that time (Tab. 2). Particulate organic matter $P O M$ was low (1-3\% of PM). Therefore, most of the PM was mineral.

There were considerable inter- and intra-annual fluctuations in the water salinity of the lakes (Tab. 2). An especially high salinity level was observed in the hot and droughty summer of 2005 . There was no correlation between the concentrations of $P_{\text {tot }}$ and water salinity, but plankton primary production was positively related to total phosphorus $\left(R^{2}=0.85, n=21\right)$. The highest values of primary production were recorded in the continental lakes (Tab. 3). Lagoon-derived lakes had lower plankton primary production and decomposition of organic matter. Most of the lakes had high levels of primary production in the winter time (Tab. 3).

The lowest value of primary production was recorded in the most saline Kojashskoe Lake in August 2004. At the same time, a very high abundance (7230 ind. $\left.\mathrm{m}^{-3}\right)$ and biomass $\left(17.87 \mathrm{gWW} \mathrm{m}^{-3}\right)$ of the grazer Artemia urmiana Günther were observed in this lake. The highest rate of primary production was documented in Kojashskoe Lake in the winter time, when the biomass of zooplankton was very low (Tab. 4). There was some increase in the ratio between the rates of primary production and decomposition of organic matter $(A / M)$ in all the lakes during the annual cycle of 2005 (Tab. 3).

\subsection{Ecosystem regime shift}

In Tobechikskoe Lake the highest rate of phytoplankton primary production was observed in August 2004. In 2005 it was much lower (Tab. 3), but very high biomass ( $\left.392 \pm 21 \mathrm{gDW} \mathrm{m}^{-2}\right)$ and primary production (1965 kJ m ${ }^{-2} \mathrm{~d}^{-1}$ ) of benthic Cladophora vadorum Kutz. and $\mathrm{Cl}$. albida Kutz. were recorded in the lake at that time. There was also a considerable decrease in the concentration of chlorophyll $a$, suspended $P M$ and suspended $P O M$ and an increase of Secchi depth in August 2005, as compared with August 2004 (Tab. 2).

Changes in the activities of primary producers in Tobechikskoe Lake were related to the differences in the weather conditions. Average $N A O$ index was positive (0.35) in 2004 and negative in $2005(-0.60)$. 
Table 4. Salinity $(S)$, abundance and biomass of zoobenthos $\left(N_{b}, B_{b}\right)$ and zooplankton $\left(N_{z p}, B_{z p}\right)$ in the saline lakes.

\begin{tabular}{|c|c|c|c|c|c|c|c|}
\hline Lake & Period & $\begin{array}{c}S \\
\% о\end{array}$ & $\begin{array}{c}\mathrm{N}_{b} \\
\text { ind. } 10^{3} \\
\mathrm{~m}^{-2}\end{array}$ & $\begin{array}{c}\mathrm{B}_{b} \\
\mathrm{~g} \mathrm{~m}^{-2}\end{array}$ & $\begin{array}{c}\mathrm{N}_{z p} \\
\text { ind. } 10^{3} \\
\mathrm{~m}^{-2}\end{array}$ & $\mathrm{~g} \mathrm{~m}_{z p}$ & $\mathrm{~B}_{b} / \mathrm{B}_{z p}$ \\
\hline Bakalskoe & Aug 2004 & 29 & 13 & 27.36 & 11.5 & 0.43 & 63.63 \\
\hline Bakalskoe & Apr 2005 & 25 & 4 & 45.87 & 0.6 & 0.02 & 2293.60 \\
\hline Bakalskoe & Aug 2005 & 38 & 16 & 173.68 & 0.16 & 0.0002 & 868400.00 \\
\hline Kirkojashskoe & Aug 2004 & 24 & 12 & 35.16 & 400.5 & 8.75 & 4.02 \\
\hline Kirkojashskoe & Apr 2005 & 30 & 43 & 75.39 & 491.1 & 19.23 & 3.92 \\
\hline Kirkojashskoe & Aug 2005 & 35 & 46 & 89.99 & 1389.8 & 22.62 & 3.98 \\
\hline Kirkojashskoe & Dec 2005 & 38 & 30 & 103.65 & 121.7 & 1.22 & 84.96 \\
\hline Shimakhanskoe & Aug 2004 & 30 & 12 & 42.88 & 1076.9 & 8.16 & 5.25 \\
\hline Shimakhanskoe & Apr 2005 & 37 & 9 & 55.23 & 448.2 & 16.28 & 3.39 \\
\hline Shimakhanskoe & Aug 2005 & 55 & 9 & 3.34 & 1314.9 & 35.75 & 0.09 \\
\hline Shimakhanskoe & Dec 2005 & 61 & 0.2 & 0.08 & 49.74 & 0.092 & 0.87 \\
\hline Tobechikskoe & Aug 2004 & 57 & 6 & 32.50 & 165.2 & 7.55 & 4.30 \\
\hline Tobechikskoe & Apr 2005 & 58 & 1 & 7.33 & 9.4 & 0.38 & 19.29 \\
\hline Tobechikskoe & Aug 2005 & 100 & 15 & 16.94 & 8.4 & 0.53 & 31.96 \\
\hline Tobechikskoe & Dec 2005 & 86 & 0.04 & 0.21 & 0.22 & 0.092 & 2.28 \\
\hline Marfovskoe & Apr 2005 & 97 & 0.3 & 0.53 & 0.1 & 1.15 & 0.46 \\
\hline Marfovskoe & Aug 2005 & 260 & 0 & 0 & 0.0 & 0.00 & - \\
\hline Marfovskoe & Dec 2005 & 131 & 0 & 0 & 0 & 0 & - \\
\hline Kojashskoe & Aug 2004 & 275 & 0 & 0 & 3.3 & 7.07 & 0 \\
\hline Kojashskoe & Apr 2005 & 184 & 0 & 0 & 12.0 & 7.19 & 0 \\
\hline Kojashskoe & Aug 2005 & 340 & 0 & 0 & 1.6 & 1.82 & 0 \\
\hline Kojashskoe & Dec 2005 & 235 & 0 & 0 & 0.04 & 0.0002 & 0 \\
\hline
\end{tabular}

There were much more windy days in April 2004, as compared with April 2005, during the period of intensive algal growth (Fig. 1A). Another interannual difference was a higher air temperature in 2005, as compared with 2004 (Fig. 1B). As a result, the salinity in Tobichikskoe Lake increased from 58\%o in August 2004 to 100\%o in August 2005. This led to the elimination of omnivores (Gammarus aequicauda) and an establishment of Artemia population, because 
predation of G. aequicauda was probably the main factor impeding the development of the large planktonic grazer A. parthenogenetica in the lake. The increase of Artemia population resulted in an increase of grazing pressure upon phytoplankton and clearance of water in the lake. Strong negative relationships between the biomass of Artemia spp. and phytoplankton primary production were recorded both in Tobichikskoe and Kojashskoe lakes (Fig. 2).

A)

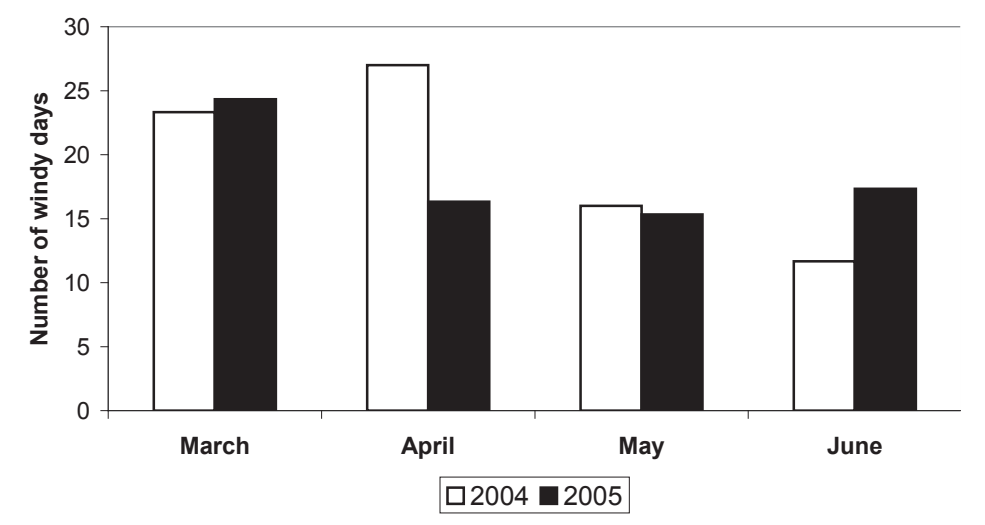

B)



Fig. 1. Number of windy days (with wind speed greater than $5 \mathrm{~m} / \mathrm{s}$ ) in a period of intensive growth of benthic filamentous algae (A) and average air temperature (B) in the eastern Crimea in 2004 and 2005. 


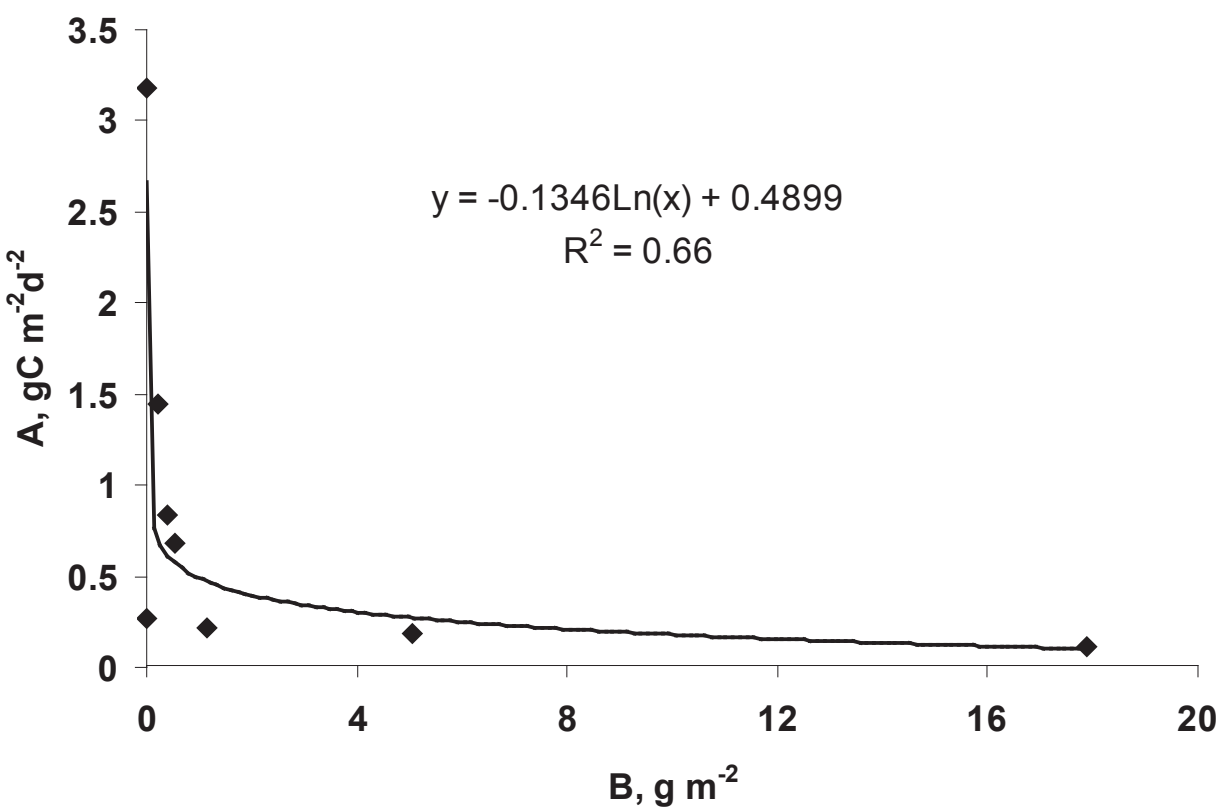

Fig. 2. Relationship between primary production of plankton (A) and biomass of Artemia spp. (B) in Tobechikskoe and Kojashskoe lakes.

\subsection{Animal communities}

The brine shrimps Artemia spp. inhabited the lakes with a salinity level of $>60 \%$. A. urmiana was the only zooplankton species in the most saline Kojashskoe Lake. A. parthenogenetica (Barigozzi) was found in the highly saline Marfovskoe Lake in August 2004 and April 2005 and in Tobechikskoe Lake after its salinity increased to 86 - $100 \%$. The other lakes had no populations of brine shrimp during the whole study period, though its cysts were found in zooplankton samples from all the lakes. Three species of mezozooplankton, the rotifer Brachionus plicatilis Müller and the crustaceans Moina mongolica and Arctodiaptomus salinus, contributed greatly to zooplankton biomass in the three less saline lakes and also in Tobechikskoe Lake, when its salinity was lower than 60\%. In addition, Daphnia ulomskyi Behning was found in small amounts in Kirkojashskoe Lake and the copepod Acartia tonsa Dana in Bakalskoe Lake. The latter (marine) 
species probably penetrated the lake from the Black Sea after a partial destruction of its spit in 2004-2005. The biomass of zooplankton in this group of lakes was low in the wintertime in December 2005 (Tab. 4). There was a dense population of planktonic A. urmiana in the most saline Kojashskoe Lake. The ration of zooplankton in August 2004 was higher than phytoplankton primary production (Tab. 5). On the other hand, there was almost no adult individuals of zooplankton in the lake in wintertime (Tab. 4), because most of the Artemia population switched to sexual reproduction and produced winter eggs. Active stages of Artemia spp. did not occur in the lakes under salinity less than $80 \%$, but resting eggs were found in all the lakes.

Larvae of Baeotendipes tauricus Tshernovskij (Chironomidae, Diptera) were widely distributed and dominant in most lakes with salinity up to $100 \%$. The most diverse fauna of bottom animals was found in Bakalskoe Lake. In addition to G. aequicauda and B. tauricus, which dominated in August 2004, the typical marine species Hediste diversicola (Müller), Polydora ciliata (Johnston) (Polychaeta), Corophiidae gen. sp. (Amphipoda) and Idotea baltica (Isopoda) were also common. These species were dominant in the bottom community in August 2005 when zoobenthic biomass reached very high values (Tab. 4). In contrast to zooplankton, there was no macrobenthos in the most saline Kojashskoe Lake and in Marfovskoe Lake at salinity greater then $97 \%$ (Tab. 4).

The highest zoobenthic biomass levels (Tab. 4), and a domination of benthic over planktonic grazing energy pathways (Tab. 5) were observed for the salinity range of $25-60 \%$. The production of benthic non-predators in Kirkojashskoe Lake at the salinity of $38 \%$ reached $33 \mathrm{~kJ} \mathrm{~m}^{-2} \mathrm{~d}^{-1}$ and their ration $-144 \mathrm{~kJ} \mathrm{~m}^{-2} \mathrm{~d}^{-1}$. A further increase in salinity led to a reduction of benthic animal communities and an increase of importance of planktonic energy pathways. In the most saline Kojashskoe Lake, where no macrozoobenthos was found, production of planktonic animals reached $4.9 \mathrm{~kJ} \mathrm{~m}^{-2} \mathrm{~d}^{-1}$ and their ration $12.03 \mathrm{~kJ} \mathrm{~m}^{-2} \mathrm{~d}^{-1}$ (Tab. 5).

There were no zooplanktonic predators in the lakes. Predatory fishes present in Bakalskoe Lake (jellyfish Rhizostoma sp. and 


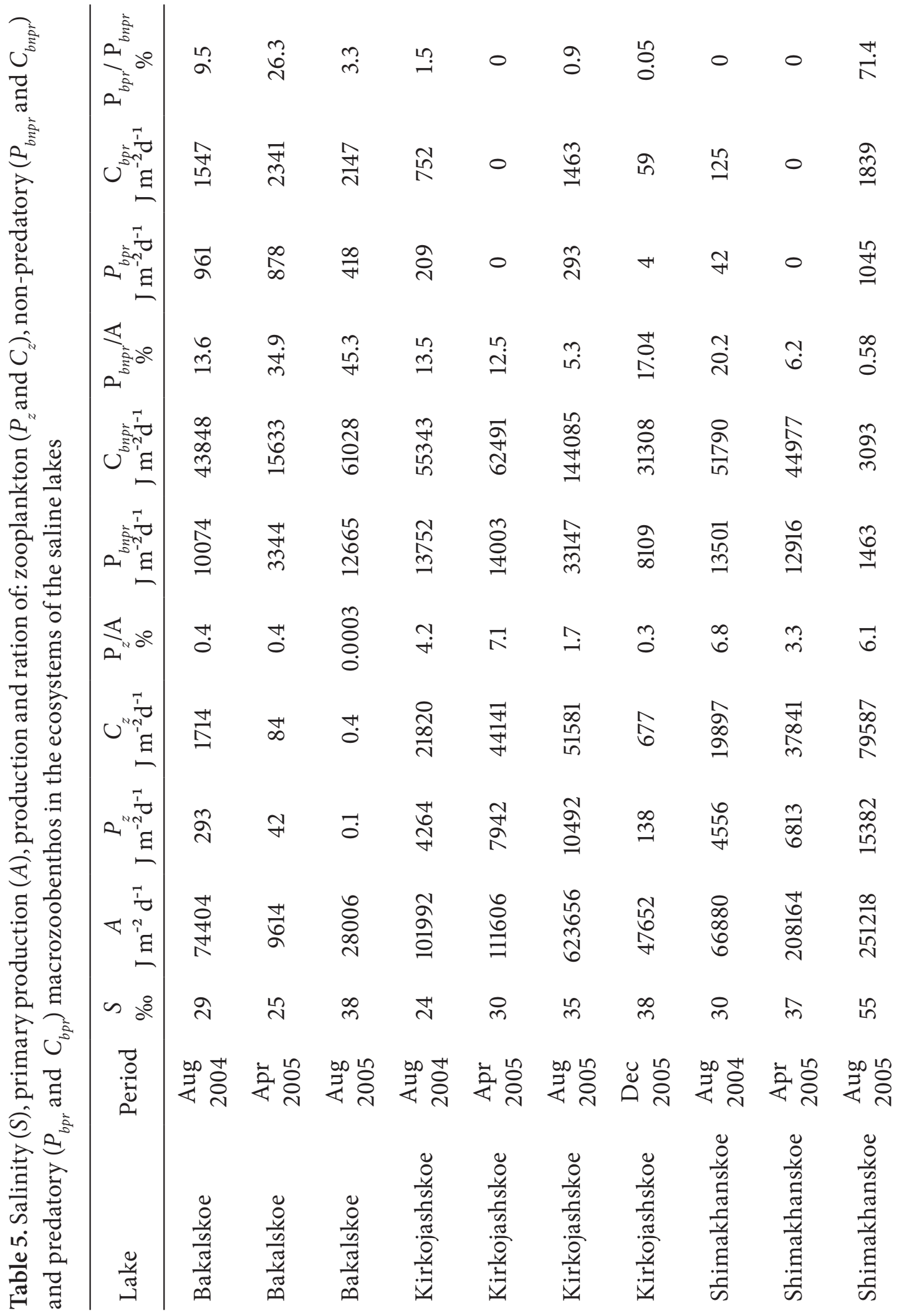




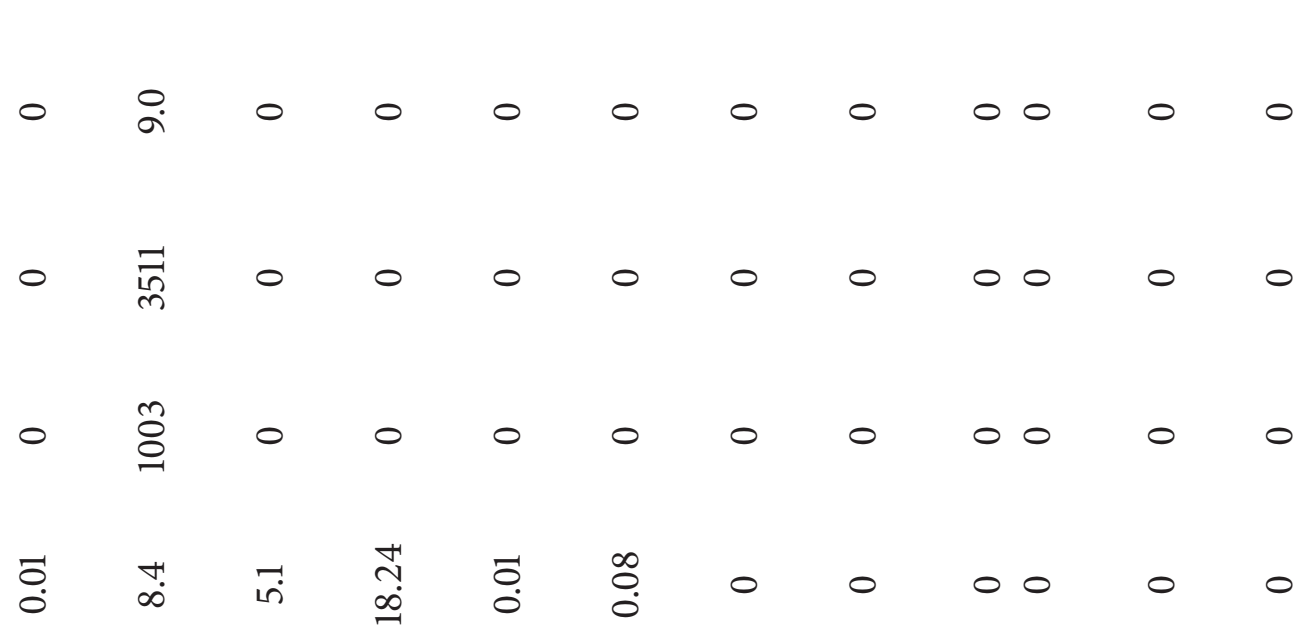

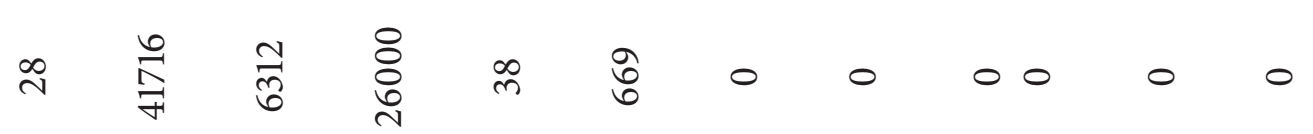

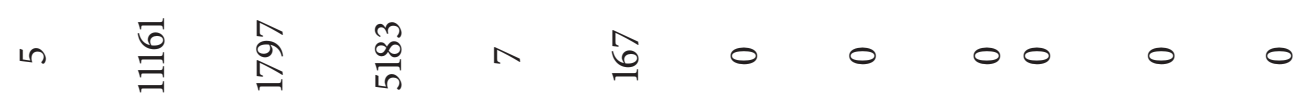

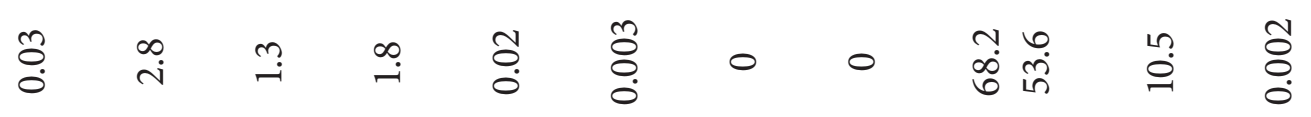

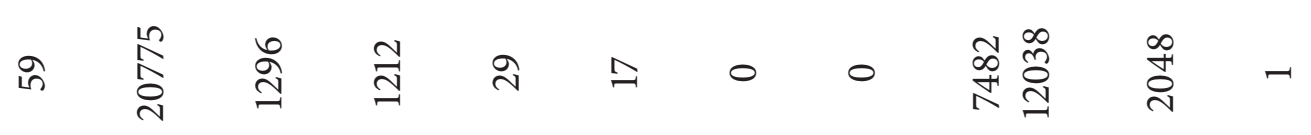



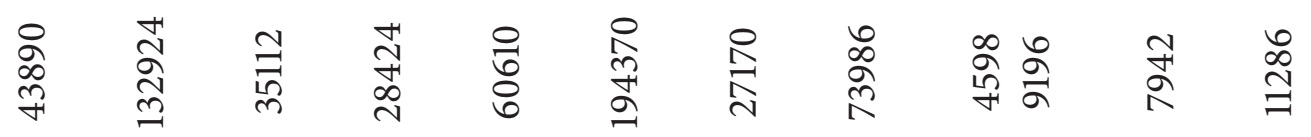

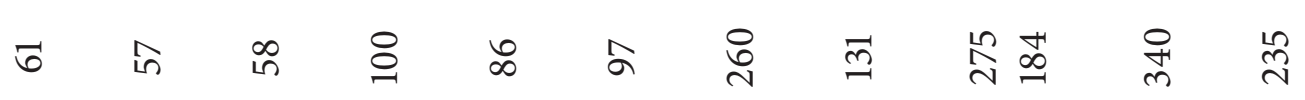



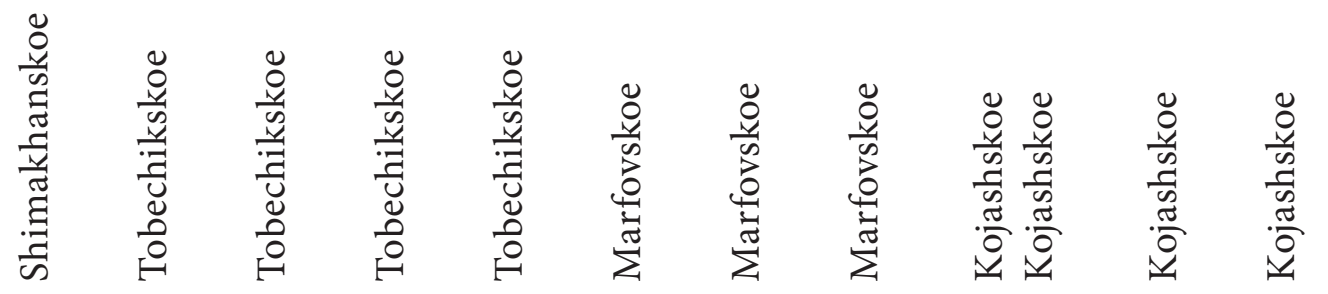


Mnemiopsis leideyi Agassiz), penetrated there from the Black Sea in 2004. Due to their large size $(5-20 \mathrm{~cm})$, they were not collected in our zooplankton samples and were not included in energy flux calculations. The predatory beetle Hygrotus enneagrammus (Ahrens) typical for saline environments, was found in the moderately saline Kirkojashskoe and Shimakhanskoe lakes. Omnivores Gammarus aequicauda Martynov (Amphipoda) occurred in Tobechikskoe and Bakalskoe lakes in August 2004. This species was not found in Tobechikskoe Lake in August 2005, when the salinity increased up to $100 \%$. Thus, benthic predators occurred in the lakes at salinity no more than 57\%o (Table 5).

\subsection{Effectiveness of the energy transfer in the lake ecosystems}

The highest effectiveness of energy transfer from the primary producers (trophic level I) to the consumers of the first order was recorded in the most saline Kojashskoe Lake (Tab. 6).

Table 6. Average rate of primary production $(A)$, production of non-predatory zooplankton $\left(P_{z}\right)$, non-predatory $\left(P_{b n p r}\right)$ and predatory $\left(P_{b p r}\right)$ zoobenthos and effectiveness of transformation of energy to the second $\left(\mathrm{II}=\left(P_{z}+P_{b n p r}\right) / A\right)$ and third $\left(\mathrm{III}=P_{b p r} / P_{b n p r}\right)$ trophic levels in the ecosystems of the saline lakes with different average salinity $(S)$

\begin{tabular}{lccccccc}
\hline Lake & $S$ & $\begin{array}{c}A \\
\% \text { o }\end{array}$ & $\begin{array}{c}P_{z} \\
\mathrm{~J} \mathrm{~m}^{-2} \mathrm{day}^{-1}\end{array}$ & $\begin{array}{c}P_{b n p r} \\
\mathrm{~J} \mathrm{~m}^{-2} \mathrm{day}^{-1}\end{array}$ & $\begin{array}{c}\mathrm{II} \\
\mathrm{J} \mathrm{m}^{-2} \mathrm{day}^{-1}\end{array}$ & $\begin{array}{c}P_{b p r} \\
\mathrm{~J} \mathrm{~m}^{-2} \mathrm{day}^{-1}\end{array}$ & $\begin{array}{c}\text { III } \\
\%\end{array}$ \\
\hline Bakalskoe & 28 & 37327 & 125 & 8694 & 23.6 & 752 & 8.5 \\
Kirkojashskoe & 33 & 221247 & 5727 & 17263 & 10.4 & 125 & 0.2 \\
Shimakhanskoe & 47 & 142538 & 6688 & 6981 & 9.6 & 293 & 0.9 \\
Tobechikskoe & 79 & 64288 & 1170 & 4556 & 8.9 & 251 & 4.4 \\
Marfovskoe & 186 & 98253 & 2 & 42 & 0.1 & 0 & 0.0 \\
Kojashskoe & 312 & 8276 & 2215 & 0 & 27.0 & 0 & 0.0 \\
\hline
\end{tabular}

The trophic structure there was very simple: the only macroinvertebrate consumer was A. urmiana. The ratios of its production and ration to primary production of plankton were on average about 27 
and $65 \%$, respectively. The lowest food web transfer effectiveness was recorded in Marfovskoe Lake, which was affected by severe eutrophication and drought in summer time. The extremely high concentration of organic matter led to anoxic conditions at night-time and to the elimination of planktonic and benthic animals from the lake. In all the lakes, transfer efficiency of energy from trophic level II to trophic level III (i.e. ratio between the production values of predatory vs. non-predatory zoobenthos) was much lower than transfer efficiency from trophic level I to trophic level II (Tab. 6). On average, they constituted 2.3 and $13.3 \%$, respectively.

Ecosystems of Kirkojashskoe and Shimakhanskoe lakes had a very low efficiency of the energy transfer to trophic level III. Ecosystems of Marfovskoe and Kojashskoe lakes had no consumers II (trophic level III) at all (Tab. 6). The best-developed trophic level III was recorded in the community of Bakalskoe Lake with the lowest level of water salinity (Tab. 6). In fact, the food chain in this lake had four trophic levels, since the fishes were also present. The energy transfer efficiency to the trophic level III was twice as lower in Tobechikskoe Lake than in Bakalskoe Lake. Hypereutrophic Kirkojashskoe and Shimakhanskoe lakes had a very low transfer efficiency to the trophic level III. The highly eutrophic and saline Marfovskoe Lake and extremely saline Kojashskoe Lake had no secondary consumers (macroinvertebrate predators) at all (Tab. 6).

\section{Discussion}

\subsection{Primary production}

All the lakes studied had a high level of primary production even in the wintertime. This resulted from lower water freezing points at high salinities and the absence of ice cover even at low air temperature, which is a characteristic feature of saline lakes in the temperate climate.

Apart from $P_{\text {tot }}$ concentration, which corresponded to eutrophic or, in some cases, to hypereutrophic conditions, according to the 
classification of Håkanson and Boulion (2001), concentration of Chl $a$ and the level of primary production $A$ were not very high and often corresponded to the levels in mesotrophic inland waters. This means that certain factors inhibited algae growth in these potentially very productive systems. Such a factor might be an increase of saline water turbidity due to its higher density and lower rate of sedimentation and higher level of resuspension of $P M$, as compared to fresh water, because the sinking velocity decrease and vertical settling flux of $P M$ increase if the difference between the fluid density and density of the particles becomes less (Bloesch 2003). A high concentration of suspended $P M$ reduces light penetration into the lake water and may constrain the primary production of phytoplankton (Hamilton and Mitchell 1996). Thus, the concentration of $P M$ reached almost $1 \mathrm{~kg}$ $\mathrm{m}^{-3}$ in April and August 2005 in the most saline Kojashskoe Lake and the Secchi depth was only about $0.2 \mathrm{~m}$ at that time. Concentration of $P O M$ was low (1-3\% of $P M)$, hence, most of the $P M$ was mineral. A low water transparency induced by a resuspension of mineral particles, may be one of the reasons for rather a low Chl $a$ or $A$ values in highly saline lakes, despite the high $P_{\text {tot }}$ concentrations.

There were strong negative relationships between the levels of biomass of filtrators (Artemia spp.) and of phytoplankton primary production in the lakes. Thus, a high pressure of herbivore zooplankton may be another factor responsible for relatively low levels of $\mathrm{Chl}$ $a$ in the lakes. The ration of zooplankton (which consisted only of $A$. urmiana) in the most saline Kojashskoe Lake was higher than phytoplankton primary production in summer 2004 and spring 2005. On the other hand, the biomass of zooplankton in this lake was very low in winter, because most of the Artemia population switched to sexual reproduction and produced winter eggs. As a result, concentration of Chl a was much higher in winter than in spring and summer. Therefore, the organic matter produced during winter was stored as lake detritus and could be used by brine shrimp in spring and summer. The content of $P O M$ was the highest in winter and especially high in spring after the period of low biomass of A. urmiana. It should also be mentioned that Kojashskoe Lake is the only place in Europe 
where this species of Artemia was recorded (Abatzopoulos et al. 2009). Additionally nitrogen content can also be critical to algal growth in saline lakes (e.g. Thornton 1986).

\subsection{Ecosystem regime shifts and climatic fluctuations}

The concept of two ecosystem states, a clear-water community (dominated by macrophytes) and a turbid-water community (dominated by phytoplankton), has been developed for shallow freshwater lakes undergoing eutrophication (e.g. Scheffer 1990, 1998). According to this concept at some intermediate nutrient concentrations both states are possible. Depending on an external forcing ecosystem shift from one state to another is possible without changes in nutrient loading. Davis et al. (2003) suggested that moderate salinity results in the dominance of a small number of salt-tolerant macrophyte species (e.g. Rupia) and with increasing salinity the system shifts to benthic microbial community composed mostly of cyanobacteria and halophilic bacteria. Our investigation has shown that ecological regime of Crimean shallow saline lakes is also vulnerable to climatic fluctuation. A sharp ecosystem shift from turbid to clear water state was observed in Tobechikskoe Lake in 2005. A considerable decrease of phytoplankton primary production, $P M, P O M$ and $C h$ $a$ concentrations and increase of Secchi depth and biomass of benthic filamentous macroalgae were observed in this lake in August 2005, as compared with August 2004.

The changes in the community of primary producers in Tobechikskoe Lake were in accordance with differences in the weather conditions. Average $N A O$ index calculated for spring and summer months was positive (0.35) in 2004 and negative in $2005(-0.60)$. The positive $N A O$ index corresponds to cyclonic windy and rainy conditions, whereas the negative one to anticyclonic conditions and relatively sunny weather in the temperate zone of Europe. Indeed, there were much more windy days in the eastern Crimea in April 2004 than in 2005 (NAO indices were 1.15 and -0.30 , respectively) during the period of intensive algal growth. The windy conditions should 
result in intensive resuspension of bottom sediments, decrease of water transparency and light limitation for Cladophora growth at the bottom of the lake. As is known, a resuspension of bottom sediments by wind in shallow lakes prevents the recolonisation by macrophytes (Blindow et al. 2002), because the high turbidity restricts the growth of submerged vegetation by light limitation.

Another difference in weather conditions was a warmer vegetation season in 2005 than 2004. As a result, salinity in Lake Tobechikskoe increased almost twice in summer 2005 as compared to summer 2005. This led to the elimination of omnivores G. aequicauda and establishment of Artemia population in the lake because predation of $G$. aequicauda was, probably, the main factor impeding the development of large planktonic grazer A. parthenogenetica in the lake. A vulnerability of Artemia to vertebrate and invertebrate predators was earlier pointed out by many authors (e.g. Wurtsbaugh 1991, Williams 1998). The establishment of Artemia population in Tobechikskoe Lake resulted in an increase of grazing pressure upon phytoplankton and clearance of water in the lake, which could have facilitated the stabilization of clear water state. Strong negative relationships between the biomass of Artemia spp. and phytoplankton primary production were found in both Tobechikskoe and Kojashskoe lakes. The increase of water transparence in Tobechikskoe Lake facilitated the growth of bottom filamentous algae of Cladophora spp., which further impeded resuspension in the lake and contributed to the considerable decrease of PM, POM, and the increase of Seccchi depth in August 2005 (as compared with 2004). The ability of submerged vegetation to enhance water clarity by reducing resuspension of bottom material, suppressing algal growth, competing for nutrients and releasing allelopathic substances has been shown for freshwater lakes (e.g. Takamura et al. 2003, James et al. 2004, Gross et al. 2007).

The regime shift in Tobechikskoe Lake was induced by a primary salinization as resulted from the changes in weather conditions. Such regime shifts may also be induced by a secondary (anthropogenic) salinization. For instance, that was the case in the Crimean Saki Lake with turbid water at salinity of 65\% ( in 1987). In 1989-1990 the water 
salinity increased to $90-120 \%$, after a small freshwater inflow brook had been dammed to increase production and quality of therapeutic mud (Ivanova et al. 1994). In 1990 the biomass of Artemia increased 5 -fold and the primary production of phytoplankton decreased 25fold causing a shift from turbid to clear water stage. Dense mats of Cladophora sp. were established at the bottom accounting for $96 \%$ of the primary production.

In the case of lagoon-derived lakes, there may occur one more impact of weather conditions on ecosystem water regime: thus, in 2004 windy conditions resulted in a partial destruction of the spit of Bakalskoe Lake. In the previous years, when the spit was intact and water salinity was higher, dense mats of Cladophora covered the bottom of the lake (Shadrin et al. 2004), and its ecosystem had a clear-water regime. However, after the spit was partly destroyed, Bakalskoe Lake became turbid with a high level of phytoplankton production and no benthic Cladophora mats could be found. A similar ecosystem shift that resulted from a change in weather conditions, was observed in a hypersaline coastal Araruama Lagoon in Brazil (Moreira-Tureq 2006). Thus, fluctuations in weather conditions are a principal factor responsible for a great variability of ecosystem regimes in hypersaline lakes and lagoons.

In the scheme of evolution of Australian saline lakes as a result of their salinization and eutrophication proposed by Sim et al. (2006b), the initial lake ecosystem state is a macrophyte-dominated clear-water stage with the upper salinity threshold $30-40 \%$. A further salinization leads to a clear-water regime characterized by a benthic microbial community, if there is no eutrophication of the system. In the saline Crimean lakes we observed a more complicated ecosystem dynamics resulting from changes in weather conditions and hydrological regime. An increase of salinity in lagoon-derived lakes led to regime shifts from turbid to clear water stage, where macroalgae (Cladophora spp.) play the role of macrophytes. Similarly to the macrophytes, they prevent resuspension of bottom sediments and incorporate and store nutrients from the water column. It is important, that in contrast to macrophyte-dominated stage with the upper limit of salinity up to 
30-40\%o (Sim et al. 2006a), the macroalgae-dominated stage occurs at more saline conditions, about $100 \%$. The trigger factor for such a shift must be the change in the community structure: the disappearance of predators and a development of population of large grazers (Artemia), which increase a top-down effect of zooplankton.

A further increase of salinity (higher than 100\%) in lagoon-derived lakes leads to a collapse of benthic energy pathways and a development of planktonic energy pathways due to dense populations of Artemia species. This stage was observed in the highly saline Kojashskoe Lake. In spite of a high concentration of nutrients in the water column, the biomass of phytoplankton for the most part of the year corresponded more to the clear water stage, due to a high clearance rate of zooplankton and high turbidity of the water, which was mostly related to inorganic suspended matter. Therefore, at a very high salinity in shallow lakes one may observe a "pseudo turbid" stage. In this case a high turbidity is a result of a high water density and low sedimentation rate of $P M$, but not of a high phytoplankton production level. In some specific conditions, a dominance of benthic microbial communities is also possible. In the Crimea such communities were observed in saline very shallow waters (up to 15 $\mathrm{cm}$ ), where wave action was limited. In more deep waters microbial mats are easily detached from the bottom sediments.

\subsection{Dynamics of food-webs along the salinity gradient}

As in the other saline lakes (e.g. Timms 1981), there was rather a steep decrease in zoobenthic biomass in the Crimean lakes as salinity increased. The upper limit of salinity for macrozoobenthos was about $100 \%$. One of the reasons for deterioration of benthic animal communities in these lakes is a low oxygen saturation of water at high salinity (Golubkov et al. 2007). Another possible reason may be a positive buoyancy of animals under high salinity levels. Water with salt concentration of $100-110 \%$ has the density close to body density of animals, for example, of the benthic amphipod Gammarus pulex (Moore et al. 1997). Therefore, a higher salinity leads to positive 
buoyancy for benthic species and their incapacity to colonize bottom environments. Body density of planktonic species, as a rule, is lower than that of the benthic ones. For instance, neutral buoyancy for Artemia franciscana is observed at salinity $43-48 \%$. Salinities of $100 \%$ and higher considerably decrease the downward swimming of this species and constrain the animals at the top of the water column (Davenport and Healy 2006).

Well developed trophic level III (macroinvertebrate predators) was observed only in the ecosystem of Bakalskoe Lake with the lowest level of salinity and moderate level of primary production among the investigated lakes. Hypereutrophic Kirkojashskoe and Shimakhanskoe lakes had very low energy transfer efficiencies to the level of secondary consumers, probably, due to a high level of eutrophication. The highly eutrophic and saline Marfovskoe Lake and the extremely saline Kojashskoe Lake had no secondary consumers at all. Therefore, both salinization and eutrophication of saline lakes may negatively affect higher trophic levels and shorten community food chains.

A similar effect was described for multitrophic aquatic ecosystems affected by acidification stress. It has been shown, that as acidity increases, species more frequently disappear from the higher than lower trophic levels (Petchey et al. 2004). Several mechanisms - longer generation times, lack of resting stages and dependence of species of higher trophic levels on the presence of species at lower trophic level - were suggested to explain this regularity. Thus, a shortening of food chain may be considered as a general community response to different environmental stressors: salinization, eutrophication and acidification.

\section{Conclusions}

The investigation of Crimean salt lakes has shown several ecosystem states along a salinity gradient: a turbid phytoplankton-dominated state at relatively low salinities $(<60 \%)$, a clear-water macroalgae-dominated state at intermediate salinities (up to $100 \%$ ), and a "pseudo turbid" state of highly saline lakes (probably $>150 \%$ ). 
In the latter case a high turbidity is the result of a high water density and low sedimentation rate of particulate matter, but not of a high level of phytoplankton production (as in lakes with lower salinity).

In general, the importance of energy pathways through planktonic food-webs increases with salinity due to positive buoyancy for benthic species and their incapacity to colonize bottom environments in highly saline lakes. Therefore, high water density may be an important factor affecting food web structure and ecosystem regime in hypersaline lakes.

Ecosystems of hypersaline lakes have low resilience to external factors. Fluctuations in weather conditions are the principal factor responsible for the great variability of energy pathways and ecosystem regime shifts in hypersaline lakes and lagoons. Both salinization and eutrophication of saline lakes negatively affect higher trophic levels and result in shortening of food chains.

\section{Acknowledgments}

We are grateful to Dr. N.V. Shadrin and Mr. O.E. Eremin for providing some basic characteristics of the lakes and for their help in the organization of field works. We are also grateful to the two anonymous reviewers for their valuable comments on the earlier version of the manuscript. The investigation was supported financially by the INTAS program (project no. 03-51-6541), by grants from the President of the Russian Federation, programs of Russian Academy of Sciences (Animate Nature and Biological Resources of Russia) and by the Russian Foundation for Basic Research, grant no. 11-04-00591a. This paper was presented during the V Russian-Polish School of Young Ecologists organized by Center for Ecological Research Polish Academy of Sciences, which took place in Gdańsk in September 2012.

\section{References}

Abatzopoulos T. J., Amat F., Baxevanis A.D., Belmonte G., Hontoria F., Maniatsi S., Monscatello S., Mura G., Shadrin N., 2009, 
Updating geographic distribution of Artemia urmiana Günter, 1890 (Branchiopoda: Anostraca) in Europe: an integrated and interdisciplinary approach, Internat. Rev. Hydrobiol. 94, 560-579.

Alcorlo P., Baltanás A., Montes C., 2001, Food-web structure in two shallow salt lakes in Los Monegros (NE Spain): energetic vs dynamic constraints, Hydrobiologia 466, 307-316.

Balushkina E.V., 1987, Functional importance of chironomid larvae in continental water bodies, Nauka, Leningrad, (in Russian).

Balushkina E.V., Winberg G.G., 1979, Dependence between body length and body weight of planktonic crustacean, in: G.G. Winberg (ed.), Experimental and field investigations of biological fundamentals of lakes productivity, Zoological Institute AN USSR, Leningrad, 58-79 (in Russian).

Balushkina E.V., Petrova N.P., 1989, Functioning of chironomid populations in hypersaline lakes of Crimea, Proc. Zool. Inst. Acad. Sci. USSR 205, 129-140 (in Russian).

Blindow I., Hargeby A., Andersson G., 2002, Seasonal changes of mechanisms maintaining clear water in a shallow lake with abundant Chara vegetation, Aquatic Botany 72, 315-334.

Bloesch J., 2003, Sedimentation and lake sedimentation formation, in: P.E. O'Sullivan, C.S. Reynolds (eds), The lakes handbook, Volume 1. Limnology and limnetic ecology, Blackwell Publishing, Oxford, 197-229.

Davenport J., Healy A., 2006, Relationship between medium salinity, body density, buoyancy and swimming in Artemia franciscana larvae: constraints on water column use?, Hydrobiologia 556, 295-301.

Davis J.A., McGuire M., Halse S.A., Hamilton D., Horwitz P., McComb A.J., Froend R.H., Lyons M., Sim L., 2003, What happens when you add salt: predicting impacts of secondary salinisation on shallow aquatic ecosystems by using an alternative-states model, Aust. J. Botany 51, 715-724.

Finogenova N. P., Lobasheva T. M., 1987, Growth of Tubifex tubifex Muller (Oligochaeta, Tubificidae) under various trophic conditions, Internat. Rev. Hydrobiol. 72, 709-726. 
Galkovskaya G.A., 1980, Rate of oxygen comsumption by rotifers from natural populations, Proc. Acad. Sci. BUSR, Ser. Biol. Sci. 8, 114-116 (in Russian).

Golterman H. L. (ed.), 1969, Methods for chemical analysis of freshwaters. IBP Handbook, No 8, Blackwell Scientific Publications, Oxford and Edinburgh.

Golterman H.L., 1975, Physiological limnology, Elsevier Scientific Publishing Company, Amsterdam, Oxford.

Golubkov S. M., 2000, Functional ecology of aquatic insects, Proc. Zoological Institute RAS, St.Petersburg.

Golubkov S., Kemp R., Golubkov M., Balushkina E., Litvinchuk L., Gubelit Y., 2007, Biodiversity and the functioning of hypersaline lake ecosystems from Crimea Peninsula (Black Sea), Archiv für Hydrobiologie 169, 79-87.

Gross E.M., Hilt S., Lombardo P., Mulderij G., 2007, Searching for allelopathic effects of submerged macrophytes on phytoplanktonstate of the art and open questions, Hydrobiologia 584, 77-88.

Håkanson L., Boulion V.V., 2001, Regularities in primary production, Secchi depth and fish yield and a new system to define trophic and humic state indices for lake ecosystem, Internat. Rev. Hydrobiol. $86,23-62$.

Håkanson L., Boulion V.V., 2002, The lake foodweb-modeling predation and abiotic/biotic interactions, Backhuys Publishers, Leinden.

Hamilton D.P., Mitchell S.F., 1996, An empirical model for sediment resuspension in shallow lakes, Hydrobiologia 317, 209-220.

Hemmingsen A.M., 1960, Energy metabolism as related to body size and respiratory surfaces, and evolution, Rept. Steno Memor. Hospital 9, 7-110.

Ivanova M.B., Balushkina E.V., Basova S.L., 1994, Structural-functional reorganization of ecosystem of hypehaline lake Saki (Crimea) at increased salinity, Russian Journal of Aquatic Ecology 3, 111-126.

James W.F., Barko J.W., Butler G.M., 2004, Shear stress and sediment resuspension in relation to submersed macrophyte biomass, Hydrobiologia 515, 181-191. 
Kamliuk L.V., 1974, Respiration of free living flatworms and tubemakers and factors affecting it, Journal of General Biology 35, 874-885 (in Russian).

Khmeleva N.N., 1968, Energy trade-off upon respiration, growth and reproduction of Artemia salina L., Sea Biology 15, 71-98 (in Russian).

Moore P.G., Davenport J., Middleton N.E., 1997, On the density of certain Amphipoda and Isopoda, J. Mar. Biol. Assoc. UK 78, 1-11.

Moreira-Tureq P. F., 2006, Impact of low salinity years on the metabolism of a hypersaline coastal lagoon (Brazil), Hydrobiologia 429, 133-140.

Panov V. E.,1988, Growth and production of Amphipoda in: A.F. Alimov (ed.), Communities offreshwater invertebrates in reed-beds, Proc. Zool. Inst. Acad. Sci. USSR, Leningrad, 150-160 (in Russian).

Petchey O.L., Downing A.L., Mittelbach G.G., Persson L., Steiner F., Warren P.H., Woodward G., 2004, Species loss and the structure and functioning of the multitrophic aquatic systems, Oikos 104, 467-478.

Pinder A. M., Halse S.A., McRae J.M., Shiel R.J., 2005, Occurrence of aquatic invertebrates of the wheatbelt region of Western Australia in relation to salinity, Hydrobiologia 543, 1-24.

Ruttner-Kolisko A., 1977, Suggestions for biomass calculation of plankton rotifers, Arch. Hydrobiol. Ergebn. Limnol. 8, 71-78.

Salazkin A. A., Ivanova M.B., Ogorodnikova V.A., 1984, Methodic recommendations on the collection and treatment of materials during hydrobiological researches on fresh water bodies. Zooplankton and its production, State Research Institute of Lake and River Economy, Leningrad (in Russian).

Scheffer M., 1990, Multiciplity of stable states in freshwater system, Hydrobiologia 200/201, 475-486.

Scheffer M., 1998, Ecology of shallow lakes, Chapman and Hall, London. Segal R.D., Waite A.M., Hamilton D.P., 2006, Transition from planktonic to benthic algal dominance along a salinity gradient, Hydrobiologia 556, 119-135.

Shadrin N.V., Golubkov S.M., Balushkina E.V., Orleanskii V.K., Mikhodyuk O.S., 2004, Response of the ecosystem of hypersaline 
Lake Bakalskoye (Crimea) to climatic characteristics of 2004, Marine Ecolological Journal 3, 74 (in Russian).

Sim L.L., Chambers J.M., Davis J.A., 2006a, Ecological regime shifts in salinised wetland systems. I. Salinity thresholds for the loss of submerged macrophytes, Hydrobiologia 573, 89-107.

Sim L.L., Davis J.A., Chambers J.M., 2006b, Ecological regime shifts in salinised wetland systems. II. Factors affecting the dominance of benthic microbial communities, Hydrobiologia 573, 109-131.

Strachlow K., Davis J., Sim L., Chambers J., Halse S., Hamilton D., Horwitz P., McComb A., Froend R., 2005, Temporal changes between ecological regimes in a range of primary and secondary salinized wetland, Hydrobiologia 552, 17-31.

Stricland J.D.H., Parsons T.R., 1968, A practical handbook of seawater analysis, Fish. Res. Board Can. Bull 167, 1-311.

Sushchenya L.M., 1972, Intensity of respiration in crustaceans, Naukova Dumka, Kiev (in Russian).

Takamura N., Kadono Y., Fukushima M., Nakagawa M., Kim B-H., 2003, Effects of aquatic macrophytes on water quality and phytoplankton communities in shallow lakes, Ecological Research, 381-395.

Timms B.V., 1981, Animal communities in three Victorian lakes of differing salinity, Hydribiologia 81/82, 181-193.

Timms B.V., 2005, Salt lakes in Australia: present problems and prognosis for the future, Hydrobiologia 552, 1-15.

Thornton J.A., 1986, Nutrients in African lake ecosystems, do we know all?, Journal of the Limnological Society of Southern Africa 12, 6-21.

Vareschi E., 1987, Saline lake ecosystems, Ecological Studies 61, 347-364. Williams W.D., 1998, Management of inland saline waters. Guidelines of lake management 6, ILEC/UNEP, Kusatsu, Japan.

Williams W.D., 2002, Environmental threats to salt lakes and the likely status of inland saline ecosystems in 2025, Environmental Conservation 29, 154-167.

Winberg G.G., 1983, Temperature coefficient of Van Goff and Arenius's equation in biology, Journal of General Biology 44, 31-42 (in Russian). 
Winberg G.G., Duncan A. (eds), 1971, Methods for the estimation of production of aquatic animals, Academic Press, London, New York. Wurtsbaugh W.A., 1991, Food-web modification by an invertebrate predator in the Great Salt Lake (USA), Oecologia 89, 168-175. 